\title{
A Review of Biologically Active Natural Products from Mediterranean Wild Edible Plants: Benefits in the Treatment of Obesity and Its Related Disorders
}

\author{
Mariangela Marrelli ${ }^{\mathbb{D}}$, Giancarlo Statti and Filomena Conforti * $\mathbb{D}$ \\ Department of Pharmacy, Health and Nutritional Sciences, University of Calabria, 87036 Rende (CS), Italy; \\ mariangela.marrelli@unical.it (M.M.); giancarlo.statti@unical.it (G.S.) \\ * Correspondence: filomena.conforti@unical.it; Tel.: +39-0984-493168; Fax: +39-0984-493107
}

Academic Editors: Roberto Fabiani and Eliana Pereira

Received: 17 January 2020; Accepted: 1 February 2020; Published: 3 February 2020

\begin{abstract}
Wild foods constitute an essential component of people's diets around the world. According to the Food and Agriculture Organization (FAO), over 100 million people in the EU consume wild foods, while 65 million collect some form of wild food themselves. The Mediterranean basin is a biodiversity hotspot of wild edible species. Nowadays, due to the renewed interest in alimurgic plants and the recent findings on the beneficial role of their phytochemical constituents, these species have been defined as "new functional foods". Research on natural products has recently regained importance with the growing understanding of their biological significance. Botanical food supplements marketed for weight and fat loss in obese subjects will be one of the most important items in marketed nutraceuticals. The aim of this report was to review the phytochemical compounds of Mediterranean wild edible species and their therapeutic potential against obesity and its related disorders. Results on the in vitro and in vivo activity of the most interesting plant extracts and their bioactive components are presented and discussed. The most interesting discoveries on their mechanisms of action are reported as well. Overall, this contribution highlights the importance and beneficial health roles of wild edible species.
\end{abstract}

Keywords: alimurgic plant; biodiversity; obesity; phytochemical compound; wild

\section{Introduction}

Plants are a constant and fundamental element of the environment that surrounds us. Until the not too distant past, wild edible plants represented a fundamental food resource for local populations (peasants, woodsmen, shepherds, etc.) during scarcity periods. Since ancient times, spontaneous plants have been commonly used in traditional Mediterranean culture for various purposes, such as food and medicines, but also for the production of clothes and magic and religious rituals. Garn and Leonard suggested that there are between 300,000 and 500,000 plant species on the planet, 30,000 of which are thought to be edible [1], and only 7000 of these have been either cultivated or collected as food. Currently, only 20 species provide $90 \%$ of the world's food requirements, with wheat, maize, and rice being the principal ones. The large-scale cultivation of a limited number of crops, together with the industrial revolution, lifestyle changes, and poor contact with nature, has produced an underutilization of wild dietary plants [2].

Many people, particularly in Mediterranean region, continue to use wild dietary plants in their local popular traditions. The use of spontaneous plants for culinary purpose has always been well rooted in Mediterranean region, although in many cases wild edible plants are known and used only by older people [3]. An unlearning phenomenon has been observed, referring to the situation in which 
the various uses of plants (in particular those relating to emergency foods) are still remembered but no longer practiced, and are therefore destined to be forgotten [4].

Different trends in the consumption of wild food plants are linked to economic and environmental factors. Some sociocultural factors, such as changes in livelihoods and lifestyles and legal restrictions on the collection of collect wild plants, can help to explain the decrease of wild food plant consumption, not to mention the fact that wild plants are sometime considered famine foods. On the other hand, other sociocultural factors, such as the local appreciation of taste and flavor or the search for natural and healthy foods, seem to be increasing the interest towards wild food plants $[5,6]$.

Moreover, in modern societies, a new phenomenon associated with the use of wild dietary plants is emerging. Today, food, and especially food plants, is considered not only in terms of simple nutritional intake, but as a potential source of natural products useful for human health. In many countries, the opportunity has now emerged to elaborate and propose precise indications of dietary behavior to satisfy the needs of the population to preserve their health [7]. One of the opportunities to find solutions to diversify the diet and to increase the intake of nutraceuticals can be found in the popular traditional use of wild edible plants both as a source of food and as compounds with potential therapeutic activity. There is a different sensitivity for healthy eating in different countries that recalls the specificity of the local flora and expresses itself in the local ethnobotanical traditions. Therefore, the study of local popular traditions with nutraceutical activity and their possible reintroduction into modern food diets is of great importance [8]. In many areas of Europe (mainly in Mediterranean countries), there has been a recent revival of interest in the use of dietary wild plants, which are sold in local markets [9].

Wild plants usually contain a large spectrum of plant secondary metabolites like polyphenols and terpenoids, which make them good candidates as nutraceuticals, i.e., functional foods. Numerous wild edible plants have been studied in in vitro and in vivo models and have been shown to possess potentially beneficial active principles [10]. Wild-growing plants are used by increasing numbers of people, even by professional chefs, especially in high-end restaurants. They generally are highly accepted by consumers, who often consider that "natural" means "safe". This is, however, an oversimplification, as numerous botanicals have been found to contain toxic compounds. Therefore, it is essential to provide the general public as well as healthcare professionals with adequate information regarding the benefits and the risks associated with the use of these products, thereby promoting more rational decisions in this regard [11].

\section{Phytoalimurgy}

The branch of botany focused of the rediscovery and the study of wild plants for their nutritional value is called "phytoalimurgy". This term derives from Greek and Latin words " $\varphi v \tau o ́ v$ (phytón)", which means plant, and "alimenta urgentia", which indicates the food that can be used in case of necessity and urgency [12]. This word was first coined by the Italian naturalist Giovanni Targioni Tozzetti in 1767, in his work "De alimenti urgentia", and then by the botanist Oreste Mattirolo, who added the prefix "phyto" to the word in his book "Phytoalimurgia Pedemontana" [13]. Oreste Mattirolo described how European populations have tried to solve the terrible food shortages in wartime, e.g., when wheat was not available, bread was made by mixing different kinds of flour, such as buckwheat and oak acorn flour, which are less nutritious than traditional flour.

The enhancement of the flora and its uses represents a real strategy by which to safeguard biodiversity. Biodiversity, in fact, is not just the number of species present in an area, but the manner in which the plants are grown, and is accompanied by a parallel path of man and plants. It is not by chance that the interest in ethnobotany is growing: saving this knowledge also saves the cultural identity of a population. The folk uses of plants, based on an ancient empirical knowledge, are an expression of the resilient relationship between human communities and their environment, which is influenced by different cultural and socioeconomic changes. The purpose of ethnobotanical investigation is often to select species with which to stimulate pharmacological studies. However, in the context of sustainable land management, the traditional knowledge can also be useful in the improvement of local 
products by promoting responsible tourism, particularly in nature reserves $[14,15]$. The alimurgic flora represents a strategic resource to which it is possible to associate many positive agri-food, ecological, and sociocultural values: food source, organic crops, low environmental impact, enhancement of local resources, conservation of biodiversity, conservation of traditional knowledge, income support to medium-sized companies, and introduction into the diet of new species with medicinal and nutraceutical potential [14].

\section{Obesity and Related Disorders}

Obesity is currently one of the main public health concerns since it is a major contributor to the global burden of chronic diseases, including cardiovascular disease, non-alcoholic fatty liver disease, type 2 diabetes mellitus, and certain types of cancer. Obesity is reaching epidemic proportions worldwide, with tripled prevalence in many European countries and affecting a large percentage of the population. Obesity and related disorders are commonly perceived as problems of rich countries, but they are increasingly present even in poor countries [16].

Guh and co-workers studied the incidence of comorbidities related to obesity and overweight. Eighteen comorbidities were identified, particularly diabetes, cardiovascular diseases, coronary heart disease, hypertension, colorectal cancer, gallbladder cancer, pancreatic cancer, ovarian cancer, and asthma, from which the authors concluded that overweight and obesity will have a significant impact on healthcare costs [17].

The increasing prevalence of obesity is a major cause of the development of metabolic syndrome, otherwise known as syndrome $X$. It is a common metabolic disorder that reflects overnutrition and sedentary lifestyles, and is linked to abdominal obesity, insulin resistance and diabetes, blood lipid disorders, inflammation, and increased risk of developing cardiovascular diseases [18-20]. Metabolic syndrome has been defined by the WHO as a pathological condition characterized by abdominal obesity, insulin resistance, hypertension, and hyperlipidemia [21].

Different potential factors contribute to obesity: genetic background, diet, and physical activity being the major ones. Therefore, the treatment of obesity consists of a reduction of caloric dietary intake combined with an increase in physical activity, while a pharmacological treatment is preferred when the behavioral approach is not sufficient to obtain weight control. In the last few years, different drugs have been promoted but some of them have been successively withdrawn because of their serious adverse effects (dinitrophenol, sibutramine, rimonabant). For many years, orlistat (1; Figure 1) was the only commonly used anti-obesity drug approved by the EMEA in Europe for long-term use, while in the USA, besides orlistat, phentermine (2) was also available, even if only for short-term use [22]. Orlistat is a semisynthetic hydrogenated derivative of the natural lipase inhibitor produced by Streptomyces toxytricini and it is a potent gastrointestinal lipase inhibitor able to prevent dietary fat absorption by $30 \%$, inhibiting both pancreatic and gastric lipases. However, it has various side effects, such as diarrhea, fecal incontinence, flatulence, bloating, and dyspepsia [23,24]. Recently, four other new drugs have been introduced: lorcaserin (3) and phentermine+topiramate ER (4), approved by the FDA in 2012, and naltrexone SR/bupropion SR (5) and liraglutide (6), recently approved in both the USA and Europe. However, these new drugs may also cause a number of adverse effects [25]. 
<smiles>CCCCCCCCCCCC(CC1OC(=O)C1CCCCCC)OC(=O)C(CC(C)C)NC=O</smiles><smiles>CC(C)(N)Cc1ccccc1</smiles>

Phentermine+topiramate ER 4<smiles>CC(C)(N)Cc1ccccc1</smiles>

Phentermine 2<smiles>CC1CNCCc2ccc(Cl)cc21</smiles>

Lorcaserin 3

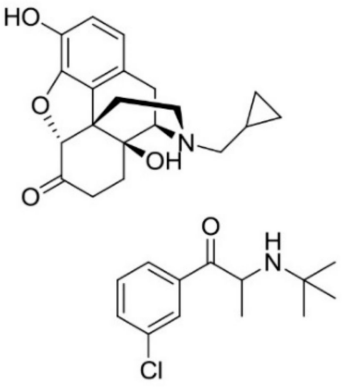

Naltrexone SR/bupropion SR 5

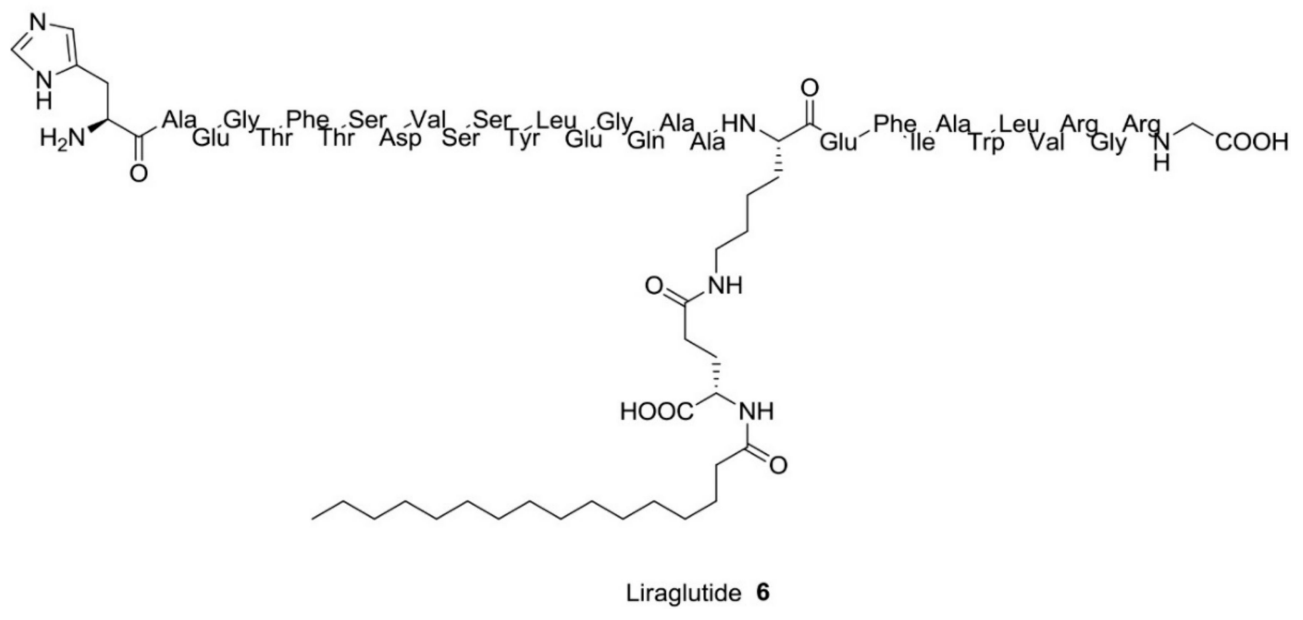

Figure 1. Current commonly used anti-obesity drugs [22,25].

\section{In Vitro and In Vivo Effects on Carbohydrate Metabolism}

The breakdown of carbohydrate by carbohydrate-digesting enzymes such as $\alpha$-amylase and $\alpha$-glucosidase and the subsequent intestinal glucose absorption remain therapeutic targets for the obesity-related disorder diabetes.

Mehanna and co-workers [26] evaluated the potential anti-obesity effect of the crude extract of Cuscuta pedicellata Ledeb. and 10 of its isolated metabolites in high-fat diet (HFD)-fed rats (Table 1). The mechanism of action included the reduction of insulin resistance and glucose tolerance, improving the cellular energy homeostasis and possession of antioxidant activity, with the most active compounds being naringenin (7; Figure 2), kaempferol (8), aromadendrin (9), quercetin (10), aromadendrin-7-O- $\beta$-D-glucoside (11), and taxifolin 7-O- $\beta$-D-glucoside (12). 
Bilberry is a European wild blueberry that contains a higher content of anthocyanins than cultivated blueberry species. Studies in animal models and clinical studies have demonstrated that the supplementation or the consumption of blueberry or blueberry bioactive compounds causes changes in glucose metabolism and improves insulin sensitivity [27]. In particular, the supplementation of $2 \%$ freeze-dried blueberry powder for 13 weeks in obese Zucker rats induced significant reductions in glucose, fasting insulin, and insulin resistance [28]. Likewise, Vuong and co-workers [29] showed that blueberry juice fermented by the Serratia vaccinia bacterium significantly reduced blood glucose levels and maintained the glycemia of pre-diabetic mice at a normal level. These results indicated that blueberry intake could reduce phenotypes of diabetes in obesity-prone rats by regulating glucose metabolism.

The effects of wild blueberry on blood glucose levels and other parameters involved in glucose metabolism were investigated in obese Zucker rats [30]. Wild blueberries are one of the richest fruit sources of anthocyanins, a class of phenolic bioactive compounds that have been shown to have insulin-sensitizing effects and to improve glucose utilization. In this study, the authors measured fasting plasma concentrations of glucose, insulin, glycated hemoglobin, resistin, and retinol-binding protein 4. The expression of resistin and glucose transporter GLUT4 genes was also determined in the liver and the abdominal adipose tissue. The results showed that plasma $\mathrm{HbA1c}$, retinol-binding protein 4 , and resistin concentrations were significantly lower after the administration of wild blueberry. According to these results, regular wild blueberry consumption could potentially help to normalize the dysregulated glucose metabolism associated with, for example, metabolic syndrome.

The hypoglycemic properties of Poncirus trifoliate (L.) Raf. juice, seed extracts, and peel essential oil were investigated via inhibition of carbohydrate-hydrolyzing enzymes [31]. All samples were able to inhibit $\alpha$-amylase and $\alpha$-glucosidase enzymes in a concentration-dependent manner. The most interesting activity was found against $\alpha$-glucosidase enzyme. In particular, juice exhibited an $\mathrm{IC}_{50}$ value of $81.27 \mu \mathrm{g} / \mathrm{mL}$, followed by seed extracts $\left(\mathrm{IC}_{50}\right.$ value of $170.54 \mu \mathrm{g} / \mathrm{mL}$ ). The same trend was observed against $\alpha$-amylase, with $\mathrm{IC}_{50}$ values of 138.14 and $459.58 \mu \mathrm{g} / \mathrm{mL}$, respectively, for juice and seed extract. The main flavonoids identified in $P$. trifoliata juice were also investigated for their inhibitory activity. All tested compounds, narirutin (13; Figure 2), poncirin (14), didymin (15), naringin (16), hesperidin (17), and neoeriocitrin (18) demonstrated $\alpha$-amylase- and $\alpha$-glucosidase-inhibitory properties in a concentration-dependent manner, being even more active against $\alpha$-amylase than the positive control acarbose (19) $\left(\mathrm{IC}_{50}\right.$ of $4.69-70.80 \mu \mathrm{M}$ vs. $\mathrm{IC}_{50}$ of $\left.77.45 \mu \mathrm{M}\right)$. Neoeriocitrin was the most active molecule against $\alpha$-amylase, with an $\mathrm{IC}_{50}$ value of $4.69 \mu \mathrm{M}$, while didymin demonstrated the most promising activity against $\alpha$-glucosidase $\left(\mathrm{IC}_{50}=4.20 \mu \mathrm{M}\right)$.

Several citrus juices are also able to exert hypoglycemic effects. The administration of Citrus paradisi Macfad. juice was found to significantly reduce rapid blood glucose levels without any effect on $1.5 \mathrm{~h}$ plasma insulin levels in non-diabetic rats [32]. Citrus medica L. cv. Diamante (Diamante citron) peel extract administered in ZDF rats exerts a dose-dependent effect on serum glucose levels. The leaves, mesocarp, and endocarp extracts of C. medica cv Diamante exerted a moderate carbohydrate-hydrolyzing enzyme inhibition [33,34]. The effects of bergamot (Citrus bergamia Risso et Poit.) juice extract on diet-induced hyperlipaemia in Wistar rats and in 237 patients with hyperlipaemia associated or not with hyperglycaemia were demonstrated by Mollace and co-workers [35].

Mollica and co-workers evaluated the in vitro enzyme inhibitory activities of extracts of different plant part (flower, stem, and bulb) from Allium scorodoprosum L. subsp. rotundum, also known as wild garlic [36]. Among tested samples, the stem extract of A. scorodoprasum was the most active inhibitor of $\alpha$-amylase. This extract contained high levels of flavonoids.

Hawash and colleagues evaluated the hydrophilic and lipophilic fractions of seven traditional edible and medicinal wild plants from Palestine for their $\alpha$-amylase inhibitory activity [37]. The plants in this study included Arum palaestinum Boiss., Malva sylvestris L., Plantago major L., Centaurea iberica Trevir. ex Spreng., Cichorium endivia L., Bituminaria bituminosa (L.) C.H. Stirt, and Sisymbrium irio L. All the samples were tested at a concentration of $100 \mu \mathrm{g} / \mathrm{mL}$. Among the studied hydrophilic fractions, 
C. iberica and C. endivia had the highest porcine pancreatic $\alpha$-amylase-inhibitory effect while those from S. irio and A. palaestinum were the most active lipophilic fractions.

Melucci and co-workers evaluated the $\alpha$-amylase and $\alpha$-glucosidase inhibitory potential of extracts from Asphodeline lutea Reichenb., collected in diverse sites in the Italian Central Apennines, at different phenological stages [38]. The results showed that the samples possessed high $\alpha$-glucosidase-inhibitory effects, particularly the roots of flowering samples. The activity on $\alpha$-glucosidase is probably due to chrysophanol (20), which was identified in all the investigated samples. This anthraquinone has been shown to inhibit mammalian intestinal $\alpha$-glucosidase activity [39].

In the study of Mzoughi and co-workers [40] the $\alpha$-amylase- and $\alpha$-glucosidase-inhibitory activities of ethanol extract from Swiss chard leaves were assessed. The wild Swiss chard (Beta vulgaris L. var. cicla) is a glycophytic belonging to the Chenopodiaceae family, distributed all over the world and employed as a green leafy vegetable for its year-round availability and low cost. The leaves ethanol extract induced significant inhibitory effects on $\alpha$-glucosidase $\left(\mathrm{IC}_{50}=0.13 \mathrm{mg} / \mathrm{mL}\right)$ and $\alpha$-amylase $\left(\mathrm{IC}_{50}\right.$ $=1.03 \mathrm{mg} / \mathrm{mL}$ ) activities. The authors attributed the observed enzymes inhibitory effects of the extract to saponins, able to inhibit gluconeogenesis and glycogenolysis. However, other molecular pathways are potentially involved and remain to be investigated. In fact, it was suggested that the enzyme inhibitory capacity of Swiss chard extract might be due to its content of flavonoids, via the inhibition of glucose transporters. Some C-glycosyl flavones, such as vitexin (21; Figure 2), isovitexin (22), orientin (23), and isoorientin (24), contained in the leaves and seeds of this species, have been found to inhibit $\alpha$-glucosidase and might be responsible for the enzyme-inhibitory activity.

The chemical composition and biological activities of different solvent extracts from wild Cotoneaster nummularia Fisch. et Mey. were evaluated by Zengin and colleagues [41]. The methanolic extract possessed very good inhibitory activity against $\alpha$-glucosidase and $\alpha$-amylase. In this case, the effective inhibitory activities of this sample were also related to their high phenolic content.

Spinola and co-workers evaluated the ability of Rubus grandifolius L. methanolic extracts to inhibit glucosidases ( $\alpha$-, $\beta$-), $\alpha$-amylase, and lipase enzymes [42]. $R$. grandifolius samples, wild berries (fully ripe) and leaves, were collected in two different locations. All the extracts strongly inhibited $\alpha$-glucosidase, showing lower $\mathrm{IC}_{50}$ values than commercial drug acarbose (19). Leaves were the most active sample, while berries showed an activity similar to the positive control 1-DNJ (1-deoxynojirimycin) (25), an effective natural inhibitor isolated from mulberry roots.

Five species of edible plants from the Calabria region (southern Italy) were investigated for their $\alpha$-amylase inhibitory potential: Borago officinalis L., Capparis sicula Veill., Echium vulgare L., Mentha aquatica L., and Raphanus raphanistrum L. subsp. raphanistrum [43]. All the samples were able to inhibit the enzyme, B. officinalis being the most active one, with an $\mathrm{IC}_{50}$ value of $31.61 \mu \mathrm{g} / \mathrm{mL}$, which was better than that reported for the widely prescribed drug acarbose, which was used as a positive control. Good inhibitory activity was also found for $E$. vulgare and $C$. sicula, with $\mathrm{IC}_{50}$ values equal to 69.18 and $72.85 \mu \mathrm{g} / \mathrm{mL}$, respectively.

Five other Mediterranean dietary plants from Calabria (Carduus pycnocephalus L., Clematis vitalba L., Lepidium sativum L., Malva sylvestris L., and Picris hieracioides L.) were also evaluated for their $\alpha$-amylase inhibitory activity [44]. The formulation obtained from C. vitalba exhibited the strongest inhibitory effect on $\alpha$-amylase ( $\mathrm{IC}_{50}=31.52 \mu \mathrm{g} / \mathrm{mL}$ ). C. vitalba extract presented a higher content in fats, mainly due to a single component. In the same extract, the content of phenols was also clearly higher [45], which could have been associated with the recorded high activity.

Saoud and co-workers tested the anti- $\alpha$-glucosidase activities of the ethyl acetate (EtOAc) and $\mathrm{n}$-butanol (n-BuOH) extracts from Anvillea radiata Coss. \& Dur. (Asteraceae). Three isolated compounds were tested as well: two epimer germacranolides, $9 \alpha$-hydroxyparthenolide (26; Figure 2) and 9ß-hydroxyparthenolide (27), and the phenolic acid 3,5-O-dicaffeoylquinic acid (28) [46]. The ethyl acetate and n-butanol extracts inhibited the enzyme with $\mathrm{IC}_{50}$ values of $0.92 \mathrm{mg} / \mathrm{mL}$ and $0.81 \mathrm{mg} / \mathrm{mL}$, respectively. Among the isolated compounds, compound 28 displayed the highest $\alpha$-glucosidase-inhibitory activity $\left(\mathrm{IC}_{50}=0.09 \mathrm{mg} / \mathrm{mL}\right)$. 
<smiles>O=C1C[C@H](c2ccc(O)cc2)Oc2cc(O)cc(O)c21</smiles>

Naringenin 7

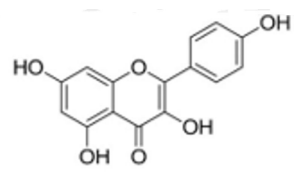

Kaempferol 8

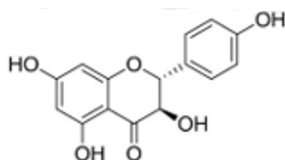

Aromadendrin 9<smiles></smiles>

Quercetin 10

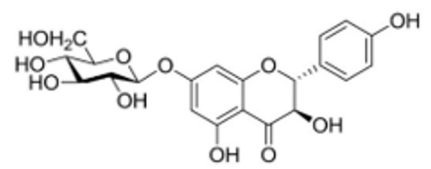

Aromadendrin7-O-b-D-glucoside 11

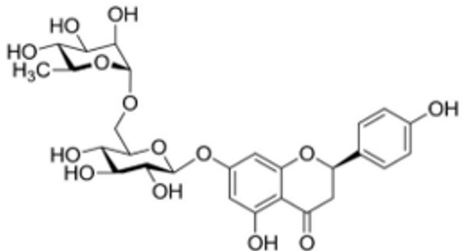

Narirutin 13

taxifolin 7-O- b-D-glucoside 12<smiles>COc1ccc([C@@H]2CC(=O)c3c(O)cc(OO[C@H]4O[C@@H](CO)[C@@H](O)[C@H](O)[C@H](O)[C@H]4O)cc3O2)cc1</smiles>

Poncirin 14

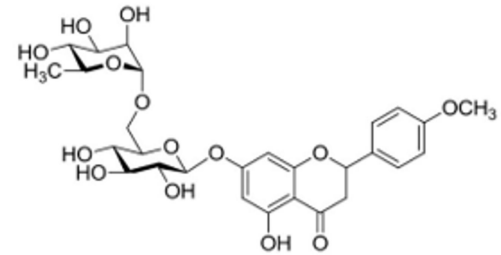

Didymin 15<smiles>COc1ccc(C2CC(=O)c3c(O)cc(OC4OC(CO)C(O)C(O)C(O)C(O)C4O)cc3O2)cc1O</smiles>

Hesperedin 17

Figure 2. Cont. 


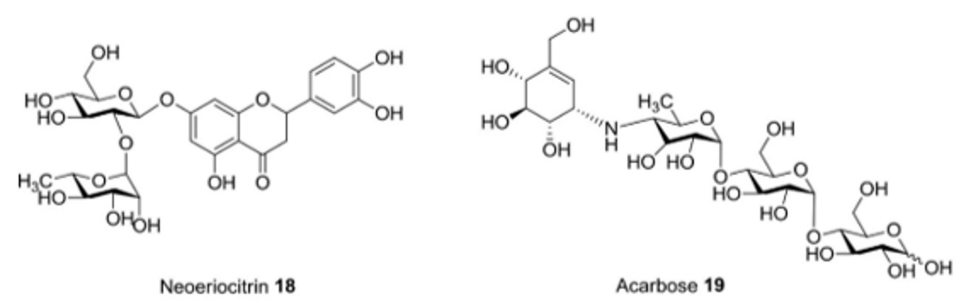

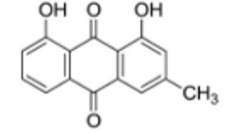

Chrysophanol 20

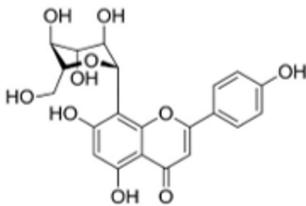

Vitexin 21

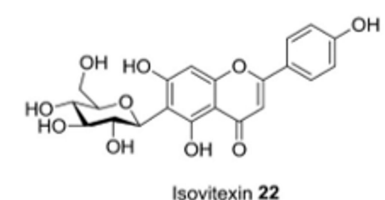<smiles>O=c1cc(-c2ccc(O)c(O)c2)oc2cc(O)c(C(O)O)c(O)c12</smiles>

Isovitexin $\mathbf{2 4}$

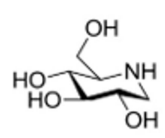

1-Deoxynojirimycin 25

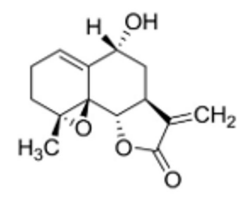

9a-hydroxyparthenolide 26

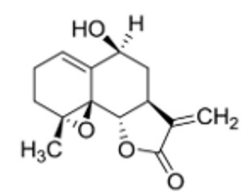

9b-hydroxyparthenolide 27<smiles>O=C(/C=C/c1ccc(O)c(O)c1)O[C@H]1[C@@H](C(=O)O)[C@@H](O)C[C@@H](OC(=O)/C=C/c2ccc(O)c(O)c2)[C@@H]1O</smiles>

Figure 2. Natural compounds with hypoglycemic properties $[26,31,36,40,42,46]$.

\section{Pancreatic Lipase Inhibition}

Lipids represent an important ingredient in human nutrition. They are essential compounds for all living organisms. Lipids are the building blocks of cellular membranes, thermal isolators, and constitute a source and reserve of body energy. However, their long-term increased intake contributes to the development of obesity and is associated with important comorbidities [47]. Agents that inhibit fat digestion can exert beneficial effects in the treatment of obesity [48]. Inhibition of the digestion of dietary lipids is a logical target for a pharmacological intervention, since it does not involve a central mechanism of action [49]. Pancreatic lipase (triacylglycerol acylhydrolase) is a key enzyme for the absorption of dietary triglycerides. Therefore, its inhibition affects fat hydrolysis and leads to a decrease of fat absorption.

Eighteen spontaneous edible plants gathered in the wild and used in the local folk tradition in the Calabria region of southern Italy, were investigated for their pancreatic lipase inhibition: Amaranthus retroflexus L., Anchusa azurea Mill., Asparagus acutifolius L., Cichorium intybus L., Diplotaxis tenuifolia (L.) DC., Foeniculum vulgare Miller subsp. piperitum (Ucria) Coutinho, Mentha spicata 
L. ssp. glabrata (Lej. et Court.) Lebeau, Origanum vulgare L. subsp. viridulum (Martin-Donos) Nyman, Papaver rhoeas L. subsp. rhoeas, Portulaca oleracea L., Raphanus raphanistrum L. subsp. landra (DC.) Bonnier \& Layens, Rosmarinus officinalis L., Rubus caesius L., Rumex conglomeratus Murray, Silene vulgaris (Moench) Garcke, Smyrnium olusatrum L., Sonchus asper (L.) Hill., and Sonchus oleraceus L. [50]. Nine extracts showed an $\mathrm{IC}_{50}$ value of less than $10 \mathrm{mg} / \mathrm{mL}$. The aqueous ethanol extracts of $P$. oleracea and S. vulgaris leaves showed the highest inhibitory potential, with $\mathrm{IC}_{50}$ values of $5.48 \mathrm{mg} / \mathrm{mL}$ and 6.02 $\mathrm{mg} / \mathrm{mL}$, respectively. Moreover, it was observed that among plant species belonging to Lamiaceae, $M$. spicata and R. officinalis showed inhibitory activity with IC $_{50}$ values of $7.85 \mathrm{mg} / \mathrm{mL}$ and $7.00 \mathrm{mg} / \mathrm{mL}$, respectively. The most interesting species belonging to Asteraceae and Brassicaceae were, respectively, S. oleraceus $\left(\mathrm{IC}_{50}=9.75 \mathrm{mg} / \mathrm{mL}\right)$ and D. tenuifolia $\left(\mathrm{IC}_{50}=7.76 \mathrm{mg} / \mathrm{mL}\right)$.

The inhibition of pancreatic lipase was also evaluated for other five edible plant species from Calabria (Italy): Borago officinalis L., Capparis sicula Veill., Echium vulgare L., Mentha aquatica L., and Raphanus raphanistrum L. subsp. raphanistrum [43]. The best pancreatic lipase inhibitory activity was reported for $C$. sicula hydroalcoholic extract, with an $\mathrm{IC}_{50}$ value of $0.5 \pm 0.03 \mathrm{mg} / \mathrm{mL}$. E. vulgare also showed effectiveness, although to a lesser extent, inducing a percentage of inhibition of $40.54 \pm 1.74$ (mean $\pm \mathrm{SD}, \mathrm{n}=3$ ) at a concentration of $2.5 \mathrm{mg} / \mathrm{mL}$. Capparis sect. Capparis has its maximum diversity in the Mediterranean region [51]. It has been reported that the phytochemical composition of Capparis species depends on ecological conditions at the site of collection (soil, exposition, water regime, etc.) [52]. Conforti and co-workers showed the biovariability of different caper species growing wild in Calabria through the detection, isolation, and quantitative evaluation of phytosterols and vitamin $\mathrm{E}$ as determined by GC/MS analysis [53]. a more detailed investigation on Capparis pancreatic lipase inhibitory activity was realized by Marrelli and co-workers [54]. Twenty accessions of the two species, Capparis orientalis Veill. and C. sicula Veill. ssp. sicula growing wild in Calabria (southern Italy) were characterized with high-performance thin-layer chromatography (HPTLC) analyses through the detection and quantitative evaluation of rutin (29, Figure 3$)$ as a typical chemical marker. The lipase-inhibitory potential of the two main metabolites, rutin and glucocapparin, was evaluated as well. All Capparis samples affected the enzyme activity in a concentration-dependent manner. $\mathrm{IC}_{50}$ values ranging from 0.73 to $2.32 \mathrm{mg} / \mathrm{mL}$ were obtained, $C$. sicula, accession no. C6 (rutin content $=25.77 \mathrm{mg} / \mathrm{g}$ of plant material), being the most effective sample. Very good activity was also observed for C. sicula no. C3, C5, C6, C8, C9, and C15, and C. orientalis no. C10, with $\mathrm{IC}_{50}$ values ranging from 0.83 to $0.96 \mathrm{mg} / \mathrm{mL}$. The biological activity of the two chemical markers, rutin (29) and glucocapparin, was also estimated. Glucocapparin did not induce inhibitory effects, while a very important activity was observed for rutin $\left(\mathrm{IC}_{50}=0.10 \mathrm{mg} / \mathrm{mL}\right)$.

Carduus pycnocephalus L., Clematis vitalba L., Lepidium sativum L., Malva sylvestris L., and Picris hieracioides L. were also investigated in order to find enzyme inhibitors [44]. These wild collected food plants are used raw, as salad (L. sativum, P. hieracioides), boiled (M. sylvestris, C. pycnocephalus), or fried (C. vitalba, C. pycnocephalus) in southern Italy. C. vitalba extract showed the best inhibitory activity with an $\mathrm{IC}_{50}$ value of $0.99 \pm 0.18 \mathrm{mg} / \mathrm{mL}$. a very good result was also obtained for L. sativum ( $\left(\mathrm{IC}_{50}=1.28 \pm 0.29 \mathrm{mg} / \mathrm{mL}\right.$ ). C. vitalba extract presented a higher content of fatty acids and phenols [45]. This extract mainly constituted chlorogenic acid, $( \pm)$-catechin, and caffeic acid.

Wild Leopoldia comosa (L.) Parl. (syn. Muscari comosum (L.) Mill.) bulbs were also investigated for their inhibitory activity on pancreatic lipase. The wild bulbs were compared with the same cultivated species that are commonly commercialized, in order to identify the samples with the best quality for potential therapeutic applications [55]. The hydroalcoholic extracts and the ethyl acetate fractions of wild bulbs showed a very important biological activity, with $\mathrm{IC}_{50}$ values equal to $0.166 \pm 0.005$ and $0.153 \pm 0.005 \mathrm{mg} / \mathrm{mL}$, respectively. Conversely, the polar fraction obtained from cultivated bulb hydroalcoholic extracts showed a significantly lower activity $\left(\mathrm{IC}_{50}=0.469 \pm 0.023\right.$ $\mathrm{mg} / \mathrm{mL}$ ), and the raw extract from cultivated samples was not effective at all. Furthermore, wild bulbs showed a phenolic content of $264.33 \mathrm{mg} / \mathrm{g}$ while cultivated ones showed a phenolic content more than six times lower $(42 \mathrm{mg} / \mathrm{g})$. 
The cooked bulbs of this plant were also investigated. Three treatments were considered: bulbs boiled in water for $15 \mathrm{~min}$ (traditional cooking method); bulbs steam-cooked for 15 min (alternative cooking method), and uncooked raw bulbs [56]. Untreated raw bulbs showed the best lipase inhibitory activity compared to steamed and boiled bulbs.

Moreover, L. comosa aerial parts (leaves and inflorescences) were also evaluated for both their phytochemical content and their biological activity [57]. The best pancreatic lipase inhibitory potential was demonstrated by the n-hexane and the ethyl acetate fractions of the leaves, with $\mathrm{IC}_{50}$ values of $0.369 \pm 0.020$ and $0.336 \pm 0.007 \mathrm{mg} / \mathrm{mL}$. The same fractions from the inflorescence sample were also effective ( $\mathrm{IC}_{50}$ values equal to $0.736 \pm 0.045$ and $0.780 \pm 0.009 \mathrm{mg} / \mathrm{mL}$, respectively). The two dichloromethane fractions induced a lower but still interesting inhibitory activity. The pancreatic lipase inhibitory activity observed for the EtOAc fractions could to a certain extent have been related to the presence of the flavonoid glycoside rutin (29), detected in both leaves and inflorescence ethyl acetate samples. The lipase inhibitory activity exerted by the inflorescence dichloromethane fraction could have been related to the presence of the identified compounds p-coumaric acid (30) and ferulic acid (31, Figure 3), two phenolic acids known for their ability to inhibit pancreatic lipase [58].
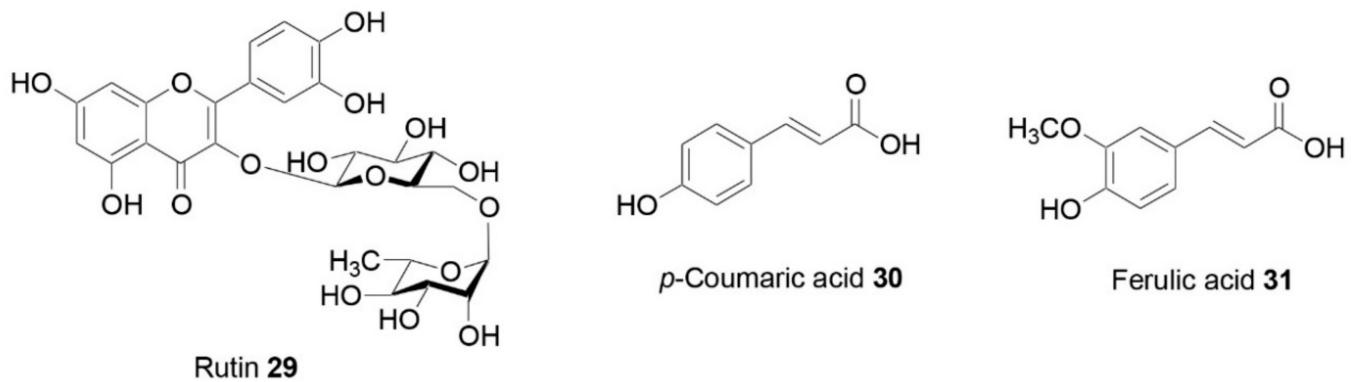

Figure 3. Phytochemicals with pancreatic-lipase-inhibitory properties [54,58].

\section{Hypolipidemic Activity}

Diets enriched with blueberries have been reported to improve dyslipidemia. Plasma triglycerides (TG) and total cholesterol (TC) concentrations were significantly reduced in obese Zucker rats supplemented with $8 \%$ wild blueberry for 8 weeks [59] or $2 \%$ blueberry powder for 13 weeks compared to the control groups [28]. a reduction in serum TC and low density lipoprotein cholesterol (LDL-C) was observed, as well as in the levels of liver TG and TC following the consumption of blueberry juice. However, the contents of liver lipids and cholesterol were not changed in C57BL/6 mice [60]. The consumption of $1 \%, 2 \%$, and $4 \%$ blueberry supplements for 8 weeks significantly reduced the TC and LDL-C concentrations in pigs [61]. The possible pathways involved in the anti-dyslipidemic effect of blueberries include the regulation and expression of key enzymes such as lipoprotein lipase (LPL) [62], fatty acid synthase [63], and ATP-binding cassette transporter 1 (ABCA1) [64], which are involved in TG and cholesterol metabolism.

Del Bo' and co-workers investigated anthocyanin- and phenolic-acid-rich fractions from wild blueberry for their capacity to counteract lipid accumulation in macrophages derived from monocytic THP-1 cells [65]. Lipid accumulation was reduced at all tested concentrations of the anthocyanins-rich fraction, with $10 \mu \mathrm{g} / \mathrm{mL}$ being the most effective concentration $(-27.4 \%)$. The phenolic-acid-rich fraction significantly reduced the lipid accumulation only at the lower concentrations (ranging from 0.05 to $0.3 \mu \mathrm{g} / \mathrm{mL})$.

\section{Inhibition of Adipogenesis}

When the intake of energy chronically exceeds energy expenditure, most excess energy is stored in the form of triglycerides in adipose tissue. Increased adipose tissue mass can arise through an increase in cell size, cell number, or both. The molecular mechanisms that regulate pre-adipose cell growth, adipose differentiation, and lipogenesis in fat cells have been extensively investigated [66]. Many studies have 
reported that obesity may induce oxidative stress [66,67]. Pre-adipocyte differentiation has become an area of intense research in recent years and has been primarily studied using in vitro models of adipogenesis, including the 3T3-L1 cell line [68,69].

Oxycoccus quadripetalus Schinz \& Thell., known as wild cranberry (syn. Vaccinium oxycoccos L.) is a good source of bioactive substances with high antioxidant potential and well documented beneficial properties. It contains vitamins, microelements, organic acids, and polyphenols such as flavonoids (quercetin, kaempferol, anthocyanin etc.). a lyophilized cranberry extract was investigated to understand its effects on precursor and mature adipocytes. Its ability to affect lipogenesis, lipolysis, and the expression of adipogenic transcription factors (PPAR $\gamma, \mathrm{C} / \mathrm{EBP} \alpha$ and SREBP1) has also been verified [70]. Cranberries reduced the proliferation and the viability of 3T3-L1 pre-adipocytes in a dose-dependent manner. Both the number of adipocytes and the lipid accumulation in maturing 3T3-L1 preadipocytes were decreased. Moreover, cranberries directly induced lipolysis in adipocytes and downregulated the expression of transcription factors of the adipogenesis pathway, such as peroxisome proliferator activated receptor gamma $(\mathrm{PPAR} \gamma), \mathrm{CCAAT} / \mathrm{enhancer} \mathrm{binding} \mathrm{protein} \mathrm{alfa}$ $(\mathrm{C} / \mathrm{EBP} \alpha)$, and sterol regulatory element binding protein 1 (SREBP1).

\section{Brown Adipose Tissue Activation}

Both the suppression of white adipose tissue (WAT) expansion and the activation of brown adipose tissue (BAT) are interesting novel potential strategies against obesity. The search for natural compounds for the browning of white adipocytes continues to attract the attention of researchers due to the possibility to find safe and novel tools against obesity [71,72]. Plant-derived essential oils (particularly spices) are a rich source of volatile compounds, and some of them, such as trans-anethole (32, Figure 4), have been demonstrated to have anti-obesity properties. In a study by Kang and co-workers, a slight intake of $100 \mathrm{mg} / \mathrm{kg}$ of trans-anethole was able to reduce body weight gain in diet-induced obese mice [73]. This molecule acts through the elevation of the expression of beige-specific genes such as Ppargc1 $\alpha$, Cited1, Prdm16, Tbx1, Ucp1, Cd137, and Tmem26. It also regulated lipid metabolism in white adipocytes via adipogenesis and lipogenesis reduction as well as lipolysis and fat oxidation elevation. Furthermore, trans-anethole showed thermogenic activity through the increase of mitochondrial biogenesis in white adipocytes and the activation of brown adipocytes.

Resveratrol (33), a natural phenol and phytoalexin produced by several plants, has been demonstrated to reduce adipose tissue inflammation, causing a decreased expression of the pro-inflammatory cytokines TNF- $\alpha$ and IL-6 in adipose tissue. This compound is also able to increase the expression of genes associated with the "browning" of adipose tissue, including UCP1 and PGC- $1 \alpha[74]$.
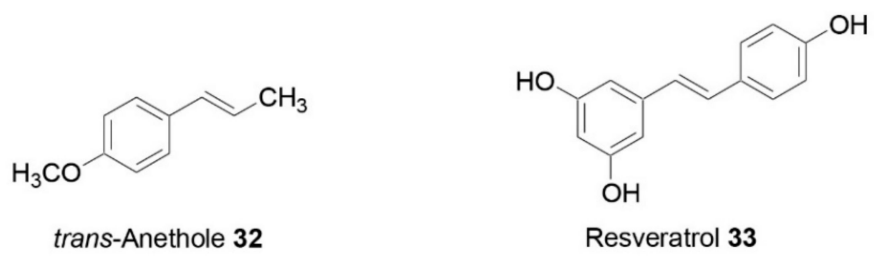

Figure 4. Phytochemical compounds acting by brown adipose tissue activation $[73,74]$. 
Table 1. Extracts from Mediterranean wild edible plants with beneficial effects against obesity and related comorbidities.

\begin{tabular}{|c|c|c|c|c|}
\hline Plant Species & Study & Activity & Class/Bioactive Compounds & References \\
\hline $\begin{array}{l}\text { Allium scorodoprosum L. subsp. } \\
\text { rotundum }\end{array}$ & In vitro & $\alpha$-Amylase-inhibitory activity & & [36] \\
\hline Amaranthus retroflexus $\mathrm{L}$. & In vitro & Pancreatic lipase inhibition & & [50] \\
\hline Anchusa azurea Mill. & In vitro & Pancreatic lipase inhibition & & [50] \\
\hline Anvillea radiata Coss. \& Dur. & In vitro & $\alpha$-Glucosidase-inhibitory activity & $\begin{array}{c}\text { 9 } \alpha \text {-hydroxyparthenolide (26), } \\
9 \beta \text {-hydroxyparthenolide (27) } \\
\text { and 3,5-O-dicaffeoylquinic acid } \\
(\mathbf{2 8})\end{array}$ & [46] \\
\hline Arum palaestinum Boiss. & In vitro & $\alpha$-Amylase-inhibitory activity & & [37] \\
\hline Asparagus acutifolius L. & In vitro & Pancreatic lipase inhibition & & [50] \\
\hline Asphodeline lutea Reichenb. & In vitro & $\alpha$-Glucosidase-inhibitory effects & Chrysophanol (20) & {$[38,39]$} \\
\hline Beta vulgaris $\mathrm{L}$. & In vitro & $\begin{array}{c}\alpha \text {-Amylase-inhibitory activity; } \\
\alpha \text {-glucosidase-inhibitory activity }\end{array}$ & $\begin{array}{c}\text { Vitexin (21), isovitexin (22), } \\
\text { orientin (23) and isoorientin (24) }\end{array}$ & [40] \\
\hline Bituminaria bituminosa (L.) C.H.Stirt & In vitro & $\alpha$-Amylase-inhibitory activity & & [37] \\
\hline Borago officinalis $\mathrm{L}$. & In vitro & $\begin{array}{c}\alpha \text {-Amylase-inhibitory activity; } \\
\text { pancreatic-lipase-inhibitory activity }\end{array}$ & & [43] \\
\hline Capparis orientalis Veill. & In vitro & Pancreatic-lipase-inhibitory activity & Rutin (29) & [54] \\
\hline Capparis sicula Veill. & In vitro & $\begin{array}{c}\alpha \text {-Amylase-inhibitory activity; } \\
\text { pancreatic-lipase-inhibitory activity }\end{array}$ & Rutin (29) & {$[43,54]$} \\
\hline Carduus pycnocephalus L. & In vitro & $\begin{array}{c}\alpha \text {-Amylase-inhibitory activity; } \\
\text { pancreatic-lipase-inhibitory activity }\end{array}$ & & [44] \\
\hline Centaurea iberica Trevir. ex Spreng & In vitro & $\alpha$-Amylase-inhibitory activity & & [37] \\
\hline Cichorium endivia $\mathrm{L}$. & In vitro & $\alpha$-Amylase-inhibitory activity & & [37] \\
\hline Cichorium intybus L. & In vitro & Pancreatic lipase inhibition & & [50] \\
\hline Citrus bergamia Risso et Poit. (bergamot) & $\begin{array}{l}\text { In vivo } \\
\text { Clinical }\end{array}$ & $\begin{array}{l}\text { Effectiveness against hyperlipaemia } \\
\text { associated or not with hyperglycaemia }\end{array}$ & & [35] \\
\hline \multirow[t]{2}{*}{$\begin{array}{l}\text { Citrus medica L. cv. Diamante } \\
\text { (Diamante citron) }\end{array}$} & In vitro & $\begin{array}{l}\text { Moderate carbohydrate-hydrolyzing } \\
\text { enzyme inhibition; }\end{array}$ & & [33] \\
\hline & In vivo & $\begin{array}{l}\text { Dose-dependent effect on serum } \\
\text { glucose levels in ZDF rats }\end{array}$ & & [34] \\
\hline Citrus paradisi Macfad. & In vivo & Rapid blood glucose reduction & & [32] \\
\hline Clematis vitalba $\mathrm{L}$. & In vitro & $\begin{array}{c}\alpha \text {-Amylase-inhibitory activity; } \\
\text { pancreatic-lipase-inhibitory activity }\end{array}$ & & [44] \\
\hline
\end{tabular}


Table 1. Cont.

\begin{tabular}{|c|c|c|c|c|}
\hline Plant Species & Study & Activity & Class/Bioactive Compounds & References \\
\hline Cotoneaster nummularia Fisch. et Mey & In vitro & $\begin{array}{c}\alpha \text {-Amylase inhibitory activity; } \\
\alpha \text {-glucosidase-inhibitory activity }\end{array}$ & & [41] \\
\hline Cuscuta pedicellata Ledeb. & In vivo & $\begin{array}{l}\text { Reduction of insulin resistance } \\
\text { and glucose tolerance }\end{array}$ & $\begin{array}{c}\text { Naringenin (7), kaempferol (8), } \\
\text { aromadenderin (9), quercetin } \\
\text { (10), aromadenderin-7-O-b-D- } \\
\text { glucoside (11), } \\
\text { taxifolin 7-O-b-D-glucoside (12) }\end{array}$ & [26] \\
\hline Diplotaxis tenuifolia (L.) DC. & In vitro & Pancreatic lipase inhibition & & [50] \\
\hline Echium vulgare $\mathrm{L}$. & In vitro & $\begin{array}{c}\alpha \text {-Amylase-inhibitory activity; } \\
\text { pancreatic-lipase-inhibitory activity }\end{array}$ & & [43] \\
\hline $\begin{array}{l}\text { Foeniculum vulgare Miller subsp. } \\
\text { piperitum (Ucria) Coutinho }\end{array}$ & In vitro & Pancreatic lipase inhibition & & [50] \\
\hline $\begin{array}{c}\text { Leopoldia comosa (L.) Parl. } \\
\text { (syn. Muscari comosum (L.) Mill.) }\end{array}$ & In vitro & Pancreatic lipase inhibition & & [55-57] \\
\hline Lepidium sativum $\mathrm{L}$. & In vitro & $\begin{array}{c}\alpha \text {-Amylase-inhibitory activity; } \\
\text { pancreatic-lipase-inhibitory activity }\end{array}$ & & [44] \\
\hline Malva sylvestris $\mathrm{L}$. & In vitro & $\begin{array}{c}\alpha \text {-Amylase-inhibitory activity; } \\
\text { pancreatic-lipase-inhibitory activity }\end{array}$ & & {$[37,44]$} \\
\hline Mentha aquatica $\mathrm{L}$. & In vitro & $\begin{array}{c}\alpha \text {-Amylase-inhibitory activity; } \\
\text { pancreatic-lipase-inhibitory activity }\end{array}$ & & [43] \\
\hline $\begin{array}{l}\text { Mentha spicata L. ssp glabrata (Lej. et } \\
\text { Court.) Lebeau }\end{array}$ & In vitro & Pancreatic lipase inhibition & & [50] \\
\hline $\begin{array}{l}\text { Origanum vulgare L. subsp. viridulum } \\
\text { (Martin-Donos) Nyman }\end{array}$ & In vitro & Pancreatic lipase inhibition & & [50] \\
\hline $\begin{array}{l}\text { Oxycoccus quadripetalus Schinz \& Thell. } \\
\text { (syn. Vaccinium oxycoccos L., wild } \\
\text { cranberry) }\end{array}$ & In vitro & Inhibition of adipogenesis & & [70] \\
\hline Papaver rhoeas L. subsp. rhoeas & In vitro & Pancreatic lipase inhibition & & [50] \\
\hline Picris hieracioides $\mathrm{L}$. & In vitro & $\begin{array}{c}\alpha \text {-Amylase-inhibitory activity; } \\
\text { pancreatic-lipase-inhibitory activity }\end{array}$ & & [44] \\
\hline Plantago major $\mathrm{L}$. & In vitro & $\alpha$-Amylase-inhibitory activity & & [37] \\
\hline
\end{tabular}


Table 1. Cont.

\begin{tabular}{|c|c|c|c|c|}
\hline Plant Species & Study & Activity & Class/Bioactive Compounds & References \\
\hline Poncirus trifoliata (L.) Raf. & In vitro & $\begin{array}{l}\text { Inhibition of carbohydrate-hydrolyzing } \\
\text { enzymes }\end{array}$ & $\begin{array}{c}\text { Nanirutin (13), poncirin (14), } \\
\text { didymin (15), naringin (16), } \\
\text { hesperidin (17), neoeriocitrin } \\
(\mathbf{1 8})\end{array}$ & [31] \\
\hline Portulaca oleracea $\mathrm{L}$. & In vitro & Pancreatic lipase inhibition & & [50] \\
\hline $\begin{array}{l}\text { Raphanus raphanistrum L. subsp. landra } \\
\text { (DC.) Bonnier \& Layens }\end{array}$ & In vitro & Pancreatic lipase inhibition & & [50] \\
\hline $\begin{array}{l}\text { Raphanus raphanistrum L. subsp. } \\
\text { raphanistrum }\end{array}$ & In vitro & $\begin{array}{c}\alpha \text {-Amylase-inhibitory activity; } \\
\text { pancreatic-lipase-inhibitory activity }\end{array}$ & & [43] \\
\hline Rosmarinus officinalis $\mathrm{L}$. & In vitro & Pancreatic lipase inhibition & & [50] \\
\hline Rubus caesius $\mathrm{L}$. & In vitro & Pancreatic lipase inhibition & & [50] \\
\hline Rubus grandifolius L. & In vitro & $\begin{array}{l}\text { Glucosidases }(\alpha-, \beta-), \alpha \text {-amylase, } \\
\text { and lipase enzyme inhibition }\end{array}$ & & [42] \\
\hline Rumex conglomeratus Murray & In vitro & Pancreatic lipase inhibition & & [50] \\
\hline Silene vulgaris (Moench) Garcke & In vitro & Pancreatic lipase inhibition & & [50] \\
\hline Sisymbrium irio $\mathrm{L}$. & In vitro & $\alpha$-Amylase-inhibitory activity & & [37] \\
\hline Smyrnium olusatrum L. & In vitro & Pancreatic lipase inhibition & & [50] \\
\hline Sonchus asper (L.) Hill. & In vitro & Pancreatic lipase inhibition & & [50] \\
\hline Sonchus oleraceus $\mathrm{L}$. & In vitro & Pancreatic lipase inhibition & & [50] \\
\hline $\begin{array}{l}\text { Vaccinium angustifolium Ait. } \\
\text { (Blueberry) }\end{array}$ & $\begin{array}{l}\text { In vitro } \\
\text { In vivo }\end{array}$ & $\begin{array}{l}\text { Reduced lipid accumulation in } \\
\text { macrophages; } \\
\text { Lowering of plasma HbA1c, } \\
\text { retinol-binding protein 4, and resistin; } \\
\text { Reduction of blood glucose levels; } \\
\text { Lowering of plasma TG, TC, } \\
\text { and LDL-C concentrations } \\
\text { - Reduction in glucose, fasting insulin } \\
\text { and insulin resistance }\end{array}$ & Antocyanins & $\begin{array}{c}{[65]} \\
{[30]} \\
{[29]} \\
{[28,59,61]} \\
{[28]}\end{array}$ \\
\hline
\end{tabular}




\section{Conclusions}

The Mediterranean diet, typical of the regions closest to the Mediterranean Sea, is considered a model of healthy eating for its contribution to a healthy status and a better quality of life. In 2013, the Mediterranean diet was inscribed on the UNESCO Representative List of the Intangible Cultural Heritage of Humanity for Italy, Spain, Portugal, Greece, Cyprus, Croatia, and Morocco [75].

This healthy diet model is based on the consumption of abundant and variable plant foods, cereals, and olive oil as the main fat. Such a dietary pattern allows a balanced ratio of n-6/n-3 essential fatty acids, and high amounts of fiber, antioxidants, and vitamins C and E [76].

It has been widely demonstrated that adherence to the Mediterranean diet exerts a significant protective effect against the major chronic degenerative diseases [77,78]. Moreover, it has been associated with a lower cancer mortality and risk of several cancer types, especially colorectal cancer [79].

The prevalence of obesity is increasing to an alarming level worldwide, and diabetes, one of obesity major comorbidities, is following the same trend. In recent years, a number of epidemiological studies have focused on the relationship between the Mediterranean diet and weight, and most of them demonstrated that the Mediterranean diet is significantly related to a decreased overweight incidence [80-82].

In the last decade, a huge number of plant extracts and their phytochemical constituents have been investigated to examine their potential anti-obesity effectiveness [83,84].

As discussed in the present review, a number of these plants belong to the Mediterranean basin.

In particular, 31 of the reviewed plant species demonstrated inhibitory potential against the pancreatic lipase enzyme. Three bioactive compounds, the flavonoid glycoside rutin and the phenolic acids p-coumaric and ferulic acids, have been proven to be effective in inhibiting this enzyme. It has also been demonstrated that two phytochemical compounds, trans-anethole and resveratrol, act through the activation of the brown adipose tissue. Moreover, wild cranberries have been demonstrated to affect adipogenesis, and a very interesting hypolipidemic activity has been observed for blueberries.

Finally, interesting effects on carbohydrate metabolism have been reported for 28 plants from Mediterranean basin and for 21 bioactive compounds isolated from these species.

Overall, numerous studies in the literature have dealt with plant extracts' and pure compounds' inhibitory activity against digestive enzymes linked to obesity and diabetes ( $\alpha$-amylase, $\alpha$-glucosidase, and pancreatic lipase). Other interesting novel potential strategies against obesity have been not fully explored, such as regarding the potential effectiveness of Mediterranean wild edible plants.

Furthermore, most of the studies reported herein were performed in vitro or in animal models. Thus, further studies are needed to corroborate these initial first results and to understand the underlying mechanisms of action, the long-term safety, and the potential toxicological effects of these plant species and their components. Such studies are needed to find new safe and effective pharmacological treatments for obesity.

Funding: M.M. was supported by a research grant from PAC CALABRIA 2014-2020 - Asse prioritario 12, Azione B) 10.5.12, CUP: H28D19000040006.

Conflicts of Interest: The authors declare no conflict of interest. 


\section{Abbreviations}

The following abbreviations have been used in the manuscript:

$\begin{array}{ll}\text { ABCA1 } & \text { ATP-binding cassette transporter 1 } \\ \text { C/EBP } \alpha & \text { CCAAT/enhancer binding protein alfa } \\ \text { EMEA } & \text { European Agency for the Evaluation of Medicinal Products } \\ \text { FAO } & \text { Food and Agriculture Organization } \\ \text { FDA } & \text { Food and Drug Administration } \\ \text { GLUT4 } & \text { Glucose transporter type } 4 \\ \text { HbA1c } & \text { Glycated hemoglobin A1c } \\ \text { HFD } & \text { High-fat diet } \\ \text { IL-6 } & \text { Interleukin 6 } \\ \text { LDL-C } & \text { Low density lipoprotein cholesterol } \\ \text { LPL } & \text { Lipoprotein lipase } \\ \text { PPAR } \gamma & \text { Peroxisome proliferator activated receptor gamma } \\ \text { SREBP1 } & \text { Sterol regulatory element binding protein 1 } \\ \text { TC } & \text { Total cholesterol } \\ \text { TG } & \text { Plasma triglycerides } \\ \text { TNF- } \alpha & \text { Tumor necrosis factor } \alpha \\ \text { UNESCO } & \text { United Nations Educational, Scientific and Cultural } \\ \text { ZDF } & \text { Organization }\end{array}$

\section{References}

1. Garn, S.M.; Leonard, W.R. What did our ancestors eat? Nutr Rev. 1989, 47, 337-345. [CrossRef] [PubMed]

2. Bailey, A.; Chandler, D.; Grant, W.P.; Greaves, J.; Prince, G.; Tatchell, M. Biopesticides: Pest Management and Regulation; CABI: Oxfordshire, UK, 2010.

3. Bacchetta, L.; Visioli, F.; Cappelli, G.; Caruso, E.; Martin, G.; Nemeth, E.; Bacchetta, G.; Bedini, G.; Wezel, A.; van Asseldonk, T. a manifesto for the valorization of wild edible plants. J. Ethnopharmacol. 2016, 191, 180-187. [CrossRef] [PubMed]

4. Sõukand, R. Perceived reasons for changes in the use of wild food plants in Saaremaa, Estonia. Appetite 2016, 107, 231-241. [CrossRef] [PubMed]

5. Menendez-Baceta, G.; Pardo-de-Santayana, M.; Aceituno-Mata, L.; Tardío, J.; Reyes-García, V. Trends in wild food plants uses in Gorbeialdea (Basque Country). Appetite 2017, 112, 9-16. [CrossRef]

6. Pieroni, A.; Soukand, R.; Quave, C.L.; Hajdari, A.; Mustafa, B. Traditional food uses of wild plants among the Gorani of South Kosovo. Appetite 2017, 108, 83-92. [CrossRef]

7. Pinela, J.; Carvalho, A.M.; Ferreira, I.C. Wild edible plants: Nutritional and toxicological characteristics, retrieval strategies and importance for today's society. Food Chem. Toxicol. 2017, 110, 165-188. [CrossRef]

8. Guarrera, P.; Savo, V. Perceived health properties of wild and cultivated food plants in local and popular traditions of Italy: a review. J. Ethnopharmacol. 2013, 146, 659-680. [CrossRef]

9. Geraci, A.; Amato, F.; Di Noto, G.; Bazan, G.; Schicchi, R. The wild taxa utilized as vegetables in Sicily (Italy): a traditional component of the Mediterranean diet. J. Ethnobiol. Ethnomed. 2018, 14, 14. [CrossRef]

10. Ceccanti, C.; Landi, M.; Benvenuti, S.; Pardossi, A.; Guidi, L. Mediterranean wild edible plants: Weeds or "new functional crops"? Molecules 2018, 23, 2299. [CrossRef]

11. Kristanc, L.; Kreft, S. European medicinal and edible plants associated with subacute and chronic toxicity part II: Plants with hepato-, neuro-, nephro-and immunotoxic effects. Food Chem. Toxicol. 2016, 92, 38-49. [CrossRef]

12. Grauso, L.; Emrick, S.; Bonanomi, G.; Lanzotti, V. Metabolomics of the alimurgic plants Taraxacum officinale, Papaver rhoeas and Urtica dioica by combined NMR and GC-MS analysis. Phytochem. Anal. 2019, 30, 535-546. [CrossRef] [PubMed]

13. Mattirolo, O.; Gallino, B.; Pallavicini, G. Phytoalimurgia pedemontana. Come Alimentarsi con le Piante Selvatiche; Blu Edizioni: Torino, Italy, 2011. 
14. Vitalini, S.; Puricelli, C.; Mikerezi, I.; Iriti, M. Plants, people and traditions: Ethnobotanical survey in the Lombard Stelvio National Park and neighbouring areas (Central Alps, Italy). J. Ethnopharmacol. 2015, 173, 435-458. [CrossRef] [PubMed]

15. Nebel, S.; Pieroni, A.; Heinrich, M. Ta chòrta: Wild edible greens used in the Graecanic area in Calabria, Southern Italy. Appetite 2006, 47, 333-342. [CrossRef] [PubMed]

16. Batal, M.; Hunter, E. Traditional Lebanese recipes based on wild plants: An answer to diet simplification? Food Nutr. Bull. 2007, 28, S303-S311. [CrossRef]

17. Guh, D.P.; Zhang, W.; Bansback, N.; Amarsi, Z.; Birmingham, C.L.; Anis, A.H. The incidence of co-morbidities related to obesity and overweight: a systematic review and meta-analysis. BMC Public Health 2009, 9, 88. [CrossRef]

18. Cornier, M.-A.; Dabelea, D.; Hernandez, T.L.; Lindstrom, R.C.; Steig, A.J.; Stob, N.R.; Van Pelt, R.E.; Wang, H.; Eckel, R.H. The metabolic syndrome. Endocr. Rev. 2008, 29, 777-822. [CrossRef]

19. Eckel, R.H.; Grundy, S.M.; Zimmet, P.Z. The metabolic syndrome. Lancet 2005, 365, 1415-1428. [CrossRef]

20. Després, J.-P.; Lemieux, I. Abdominal obesity and metabolic syndrome. Nature 2006, 444, 881. [CrossRef]

21. Saklayen, M.G. The global epidemic of the metabolic syndrome. Curr. Hypert. Rep. 2018, 20, 12. [CrossRef]

22. Marrelli, M.; Conforti, F.; Araniti, F.; Statti, G.A. Effects of saponins on lipid metabolism: a review of potential health benefits in the treatment of obesity. Molecules 2016, 21, 1404. [CrossRef]

23. Al-Suwailem, A.; Al-Tamimi, A.; Al-Omar, M.; Al-Suhibani, M. Safety and mechanism of action of orlistat (tetrahydrolipstatin) as the first local antiobesity drug. JASR 2006, 2, 205-208.

24. Kang, J.G.; Park, C.-Y. Anti-obesity drugs: a review about their effects and safety. Diabetes Metab. J. 2012, 36, 13-25. [CrossRef] [PubMed]

25. Marrelli, M.; Amodeo, V.; Statti, G.; Conforti, F. Biological properties and bioactive components of Allium cepa L.: Focus on potential benefits in the treatment of obesity and related comorbidities. Molecules 2019, 24, 119. [CrossRef] [PubMed]

26. Mehanna, E.T.; El-sayed, N.M.; Ibrahim, A.K.; Ahmed, S.A.; Abo-Elmatty, D.M. Isolated compounds from Cuscuta pedicellata ameliorate oxidative stress and upregulate expression of some energy regulatory genes in high fat diet induced obesity in rats. Biomed. Pharmacother. 2018, 108, 1253-1258. [CrossRef]

27. Shi, M.; Loftus, H.; McAinch, A.J.; Su, X.Q. Blueberry as a source of bioactive compounds for the treatment of obesity, type 2 diabetes and chronic inflammation. J. Funct. Foods 2017, 30, 16-29. [CrossRef]

28. Seymour, M.; Tanone, I.; Lewis, S.; Urcuyo-Llanes, D.; Bolling, S.F.; Bennink, M.R. Blueberry-enriched diets reduce metabolic syndrome and insulin resistance in rats. FASEB J. 2009, 23.

29. Vuong, T.; Benhaddou-Andaloussi, A.; Brault, A.; Harbilas, D.; Martineau, L.; Vallerand, D.; Ramassamy, C.; Matar, C.; Haddad, P. Antiobesity and antidiabetic effects of biotransformed blueberry juice in KKA y mice. Int. J. Obes. 2009, 33, 1166. [CrossRef]

30. Vendrame, S.; Zhao, A.; Merrow, T.; Klimis-Zacas, D. The effects of wild blueberry consumption on plasma markers and gene expression related to glucose metabolism in the obese Zucker rat. J. Med. Food 2015, 18, 619-624. [CrossRef]

31. Tundis, R.; Bonesi, M.; Sicari, V.; Pellicanò, T.; Tenuta, M.; Leporini, M.; Menichini, F.; Loizzo, M. Poncirus trifoliata (L.) Raf.: Chemical composition, antioxidant properties and hypoglycaemic activity via the inhibition of $\alpha$-amylase and $\alpha$-glucosidase enzymes. J. Funct. Foods 2016, 25, 477-485. [CrossRef]

32. Owira, P.; Ojewole, J. Grapefruit juice improves glycemic control but exacerbates metformin-induced lactic acidosis in non-diabetic rats. Methods Find. Exp. Clin. Pharmacol. 2009, 31, 563-570.

33. Menichini, F.; Loizzo, M.R.; Bonesi, M.; Conforti, F.; De Luca, D.; Statti, G.A.; de Cindio, B.; Menichini, F.; Tundis, R. Phytochemical profile, antioxidant, anti-inflammatory and hypoglycemic potential of hydroalcoholic extracts from Citrus medica L. cv Diamante flowers, leaves and fruits at two maturity stages. Food Chem. Toxicol. 2011, 49, 1549-1555. [CrossRef] [PubMed]

34. Menichini, F.; Tundis, R.; Loizzo, M.R.; Bonesi, M.; D’Angelo, D.; Lombardi, P.; Mastellone, V. Citrus medica L. cv Diamante (Rutaceae) peel extract improves glycaemic status of Zucker diabetic fatty (ZDF) rats and protects against oxidative stress. J. Enzyme Inhib. Med. Chem. 2016, 31, 1270-1276. [CrossRef] [PubMed]

35. Mollace, V.; Sacco, I.; Janda, E.; Malara, C.; Ventrice, D.; Colica, C.; Visalli, V.; Muscoli, S.; Ragusa, S.; Muscoli, C. Hypolipemic and hypoglycaemic activity of bergamot polyphenols: From animal models to human studies. Fitoterapia 2011, 82, 309-316. [CrossRef] [PubMed] 
36. Mollica, A.; Zengin, G.; Locatelli, M.; Picot-Allain, C.M.N.; Mahomoodally, M.F. Multidirectional investigations on different parts of Allium scorodoprasum L. subsp. rotundum (L.) Stearn: Phenolic components, in vitro biological, and in silico propensities. Food Res. Int. 2018, 108, 641-649. [CrossRef]

37. Hawash, M.; Jaradat, N.; Elaraj, J.; Hamdan, A.; Lebdeh, S.A.; Halawa, T. Evaluation of the hypoglycemic effect of seven wild folkloric edible plants from Palestine. J. Complement. Integr. Med. 2019. [CrossRef]

38. Melucci, D.; Locatelli, M.; Locatelli, C.; Zappi, A.; De Laurentiis, F.; Carradori, S.; Campestre, C.; Leporini, L.; Zengin, G.; Picot, C. a comparative assessment of biological effects and chemical profile of Italian Asphodeline lutea extracts. Molecules 2018, 23, 461. [CrossRef]

39. Jung, H.; Ali, M.; Choi, J. Promising inhibitory effects of anthraquinones, naphthopyrone, and naphthalene glycosides, from Cassia obtusifolia on $\alpha$-glucosidase and human protein tyrosine phosphatases 1B. Molecules 2017, 22, 28. [CrossRef]

40. Mzoughi, Z.; Chahdoura, H.; Chakroun, Y.; Cámara, M.; Fernández-Ruiz, V.; Morales, P.; Mosbah, H.; Flamini, G.; Snoussi, M.; Majdoub, H. Wild edible Swiss chard leaves (Beta vulgaris L. var. cicla): Nutritional, phytochemical composition and biological activities. Food Res. Int. 2019, 119, 612-621. [CrossRef]

41. Zengin, G.; Uysal, A.; Gunes, E.; Aktumsek, A. Survey of phytochemical composition and biological effects of three extracts from a wild plant (Cotoneaster nummularia Fisch. et Mey.): a potential source for functional food ingredients and drug formulations. PLOS ONE 2014, 9, e113527. [CrossRef]

42. Spínola, V.; Pinto, J.; Llorent-Martínez, E.J.; Tomás, H.; Castilho, P.C. Evaluation of Rubus grandifolius L.(wild blackberries) activities targeting management of type-2 diabetes and obesity using in vitro models. Food Chem. Toxicol. 2019, 123, 443-452. [CrossRef]

43. Marrelli, M.; Loizzo, M.R.; Nicoletti, M.; Menichini, F.; Conforti, F. In vitro investigation of the potential health benefits of wild Mediterranean dietary plants as anti-obesity agents with $\alpha$-amylase and pancreatic lipase inhibitory activities. J. Sci. Food Agric. 2014, 94, 2217-2224. [CrossRef] [PubMed]

44. Marrelli, M.; Loizzo, M.R.; Nicoletti, M.; Menichini, F.; Conforti, F. Inhibition of key enzymes linked to obesity by preparations from Mediterranean dietary plants: Effects on $\alpha$-amylase and pancreatic lipase activities. Plant Foods Hum. Nutr. 2013, 68, 340-346. [CrossRef]

45. Conforti, F.; Ioele, G.; Statti, G.; Marrelli, M.; Ragno, G.; Menichini, F. Antiproliferative activity against human tumor cell lines and toxicity test on Mediterranean dietary plants. Food Chem. Toxicol. 2008, 46, 3325-3332. [CrossRef] [PubMed]

46. Saoud, D.; Jelassi, A.; Hlila, M.; Goudjil, M.; Ladjel, S.; Jannet, H.B. Biological activities of extracts and metabolites isolated from Anvillea radiata Coss. \& Dur.(Asteraceae). S. Afr. J. Bot. 2019, 121, 386-393.

47. Nicolosi, R.J.; Wilson, T.A.; Lawton, C.; Handelman, G.J. Dietary effects on cardiovascular disease risk factors: Beyond saturated fatty acids and cholesterol. J. Am. Coll. Nutr. 2001, 20, 421S-427S. [CrossRef] [PubMed]

48. Scheen, A.J.; Lefebvre, P.J. Troglitazone: Antihyperglycemic activity and potential role in the treatment of type 2 diabetes. Diabetes Care 1999, 22, 1568-1577. [CrossRef]

49. Klein, S. The national obesity crisis: a call for action. Gastroenterology 2004, 126, 6. [CrossRef]

50. Conforti, F.; Perri, V.; Menichini, F.; Marrelli, M.; Uzunov, D.; Statti, G.A.; Menichini, F. Wild Mediterranean dietary plants as inhibitors of pancreatic lipase. Phytother. Res. 2012, 26, 600-604. [CrossRef]

51. Inocencio, C.; Rivera, D.; Obón, M.C.; Alcaraz, F.; Barreña, J.-A. a systematic revision of Capparis section Capparis (Capparaceae) 1, 2. Ann. Mo. Bot. Gard. 2006, 93, 122-150. [CrossRef]

52. Matthäus, B.; Özcan, M. Glucosinolates and fatty acid, sterol, and tocopherol composition of seed oils from Capparis spinosa Var. spinosa and Capparis ovata Desf. Var. canescens (Coss.) Heywood. J. Agric. Food Chem. 2005, 53, 7136-7141.

53. Conforti, F.; Modesto, S.; Menichini, F.; Statti, G.A.; Uzunov, D.; Solimene, U.; Duez, P.; Menichini, F. Correlation between environmental factors, chemical composition, and antioxidative properties of caper species growing wild in Calabria (South Italy). Chem. Biodiv. 2011, 8, 518-531. [CrossRef] [PubMed]

54. Marrelli, M.; Argentieri, M.P.; Avato, P.; Menichini, F.; Conforti, F. Inhibitory effect on lipid absorption and variability of chemical constituents from Capparis sicula subsp. sicula and Capparis orientalis. Chem. Biodiv. 2016, 13, 755-761. [CrossRef] [PubMed]

55. Marrelli, M.; La Grotteria, S.; Araniti, F.; Conforti, F. Investigation of the potential health benefits as lipase inhibitor and antioxidant of Leopoldia comosa (L.) Parl.: Variability of chemical composition of wild and cultivated bulbs. Plant Food Hum. Nutr. 2017, 72, 274-279. [CrossRef] [PubMed] 
56. Casacchia, T.; Sofo, A.; Casaburi, I.; Marrelli, M.; Conforti, F.; Statti, G.A. Antioxidant, enzyme-inhibitory and antitumor activity of the wild dietary plant Muscari comosum (L.) Mill. Int. J. Plant Biol. 2017, 8, 31-35. [CrossRef]

57. Marrelli, M.; Araniti, F.; Statti, G.; Conforti, F. Metabolite profiling and biological properties of aerial parts from Leopoldia comosa (L.) Parl.: Antioxidant and anti-obesity potential. S. Afr. J. Bot. 2019, 120, 104-111. [CrossRef]

58. Cai, S.; Wang, O.; Wang, M.; He, J.; Wang, Y.; Zhang, D.; Zhou, F.; Ji, B. In vitro inhibitory effect on pancreatic lipase activity of subfractions from ethanol extracts of fermented oats (Avena sativa L.) and synergistic effect of three phenolic acids. J. Agric. Food Chem. 2012, 60, 7245-7251. [CrossRef]

59. Vendrame, S.; Daugherty, A.; Kristo, A.S.; Klimis-Zacas, D. Wild blueberry (Vaccinium angustifolium)-enriched diet improves dyslipidaemia and modulates the expression of genes related to lipid metabolism in obese Zucker rats. Br. J. Nutr. 2014, 111, 194-200. [CrossRef]

60. Wu, T.; Tang, Q.; Gao, Z.; Yu, Z.; Song, H.; Zheng, X.; Chen, W. Blueberry and mulberry juice prevent obesity development in C57BL/6 mice. PLoS ONE 2013, 8, e77585. [CrossRef]

61. Kalt, W.; Foote, K.; Fillmore, S.; Lyon, M.; Van Lunen, T.; McRae, K. Effect of blueberry feeding on plasma lipids in pigs. Br. J. Nutr. 2008, 100, 70-78. [CrossRef]

62. Wei, X.; Wang, D.; Yang, Y.; Xia, M.; Li, D.; Li, G.; Zhu, Y.; Xiao, Y.; Ling, W. Cyanidin-3-O- $\beta$-glucoside improves obesity and triglyceride metabolism in KK-Ay mice by regulating lipoprotein lipase activity. J. Sci. Food Agric. 2011, 91, 1006-1013. [CrossRef]

63. Tsuda, T.; Ueno, Y.; Kojo, H.; Yoshikawa, T.; Osawa, T. Gene expression profile of isolated rat adipocytes treated with anthocyanins. Biochim. Biophys. Acta 2005, 1733, 137-147. [CrossRef] [PubMed]

64. Xia, M.; Hou, M.; Xia, X.; Zhu, H.; Tang, Z.; Wang, Q.; Li, Y.; Chi, D.; Yu, X.; Zhao, T. Anthocyanins induce cholesterol efflux from mouse peritoneal macrophages: The role of the PPARgamma-LXRalpha-ABCA1 pathway. J. Biol. Chem. 2005, 280, 36792-36801. [CrossRef] [PubMed]

65. Del Bo, C.; Cao, Y.; Roursgaard, M.; Riso, P.; Porrini, M.; Loft, S.; Møller, P. Anthocyanins and phenolic acids from a wild blueberry (Vaccinium angustifolium) powder counteract lipid accumulation in THP-1-derived macrophages. Eur. J. Nutr. 2016, 55, 171-182. [CrossRef] [PubMed]

66. Spiegelman, B.M.; Flier, J.S. Adipogenesis and obesity: Rounding out the big picture. Cell 1996, 87, 377-389. [CrossRef]

67. Furukawa, S.; Fujita, T.; Shimabukuro, M.; Iwaki, M.; Yamada, Y.; Nakajima, Y.; Nakayama, O.; Makishima, M.; Matsuda, M.; Shimomura, I. Increased oxidative stress in obesity and its impact on metabolic syndrome. J. Clin. Invest. 2017, 114, 1752-1761. [CrossRef]

68. Ntambi, J.M.; Young-Cheul, K. Adipocyte differentiation and gene expression. J. Nutr. 2000, 130, 3122S-3126S. [CrossRef]

69. Ruiz-Ojeda, F.J.; Rupérez, A.I.; Gomez-Llorente, C.; Gil, A.; Aguilera, C.M. Cell models and their application for studying adipogenic differentiation in relation to obesity: a review. Int. J. Mol. Sci. 2016, 17, 1040. [CrossRef]

70. Kowalska, K.; Olejnik, A.; Rychlik, J.; Grajek, W. Cranberries (Oxycoccus quadripetalus) inhibit adipogenesis and lipogenesis in 3T3-L1 cells. Food Chem. 2014, 148, 246-252. [CrossRef] [PubMed]

71. Cypess, A.M.; Kahn, C.R. Brown fat as a therapy for obesity and diabetes. Curr. Opin. Endocrinol. Diabetes Obes. 2010, 17, 143. [CrossRef]

72. Wang, Q.; Zhang, M.; Xu, M.; Gu, W.; Xi, Y.; Qi, L.; Li, B.; Wang, W. Brown adipose tissue activation is inversely related to central obesity and metabolic parameters in adult human. PLoS ONE 2015, 10, e0123795. [CrossRef]

73. Kang, N.H.; Mukherjee, S.; Min, T.; Kang, S.C.; Yun, J.W. Trans-anethole ameliorates obesity via induction of browning in white adipocytes and activation of brown adipocytes. Biochimie 2018, 151, 1-13. [CrossRef] [PubMed]

74. Gospin, R.; Sandu, O.; Gambina, K.; Tiwari, A.; Bonkowski, M.; Hawkins, M. Resveratrol improves insulin resistance with anti-inflammatory and 'browning' effects in adipose tissue of overweight humans. J. Invest. Med. 2016, 64, 814-815. [CrossRef]

75. UNESCO. Available online: https://ich.unesco.org/en/RL/mediterranean-diet-00884 (accessed on 3 January 2020). 
76. Giacosa, A.; Barale, R.; Bavaresco, L.; Gatenby, P.; Gerbi, V.; Janssens, J.; Johnston, B.; Kas, K.; La Vecchia, C.; Mainguet, P. Cancer prevention in Europe: The Mediterranean diet as a protective choice. Eur. J. Cancer Prev. 2013, 22, 90-95. [CrossRef]

77. Sofi, F.; Abbate, R.; Gensini, G.F.; Casini, A. Accruing evidence on benefits of adherence to the Mediterranean diet on health: An updated systematic review and meta-analysis. Am. J. Clin. Nutr. 2010, 92, 1189-1196. [CrossRef] [PubMed]

78. Dinu, M.; Pagliai, G.; Casini, A.; Sofi, F. Mediterranean diet and multiple health outcomes: An umbrella review of meta-analyses of observational studies and randomised trials. Eur. J. Clin. Nutr. 2018, 72, 30. [CrossRef] [PubMed]

79. Schwingshackl, L.; Schwedhelm, C.; Galbete, C.; Hoffmann, G. Adherence to Mediterranean diet and risk of cancer: An updated systematic review and meta-analysis. Nutrients 2017, 9, 1063. [CrossRef]

80. Buckland, G.; Bach, A.; Serra-Majem, L. Obesity and the Mediterranean diet: a systematic review of observational and intervention studies. Obes. Rev. 2008, 9, 582-593. [CrossRef]

81. Schröder, H. Protective mechanisms of the Mediterranean diet in obesity and type 2 diabetes. J. Nutr. Biochem. 2007, 18, 149-160. [CrossRef]

82. Schröder, H.; Marrugat, J.; Vila, J.; Covas, M.I.; Elosua, R. Adherence to the traditional Mediterranean diet is inversely associated with body mass index and obesity in a Spanish population. J. Nutr. 2004, 134, 3355-3361. [CrossRef]

83. Mopuri, R.; Islam, M.S. Medicinal plants and phytochemicals with anti-obesogenic potentials: a review. Biomed. Pharmacother. 2017, 89, 1442-1452. [CrossRef]

84. Balaji, M.; Ganjayi, M.S.; Kumar, G.E.H.; Parim, B.N.; Mopuri, R.; Dasari, S. a review on possible therapeutic targets to contain obesity: The role of phytochemicals. Obes. Res. Clin. Pract. 2016, 10, 363-380. [CrossRef] [PubMed]

(C) 2020 by the authors. Licensee MDPI, Basel, Switzerland. This article is an open access article distributed under the terms and conditions of the Creative Commons Attribution (CC BY) license (http://creativecommons.org/licenses/by/4.0/). 